\title{
KECERNAAN NDF DAN ADF YANG MENDAPAT SUPLEMENTASI UREA MOLASSES MULTINUTRIENT BLOCK (UMMB) DARI BEBERAPA JENIS LIMBAH PERTANIAN DAN RUMPUT LAPANG PADA SAPI PERANAKAN ONGOLE (PO)
}

\author{
Giandi Grahadi Turangan, B. Tulung*, Y. R. L. Tulung, M. R. Waani
}

Fakultas Peternakan Universitas Sam Ratulangi Manado. 95115

\begin{abstract}
ABSTRAK
Penelitian ini bertujuan untuk mengevaluasi kecernaan NDF dan ADF Rumput Lapang (RL) dan Limbah Pertanian yaitu Jerami Jagung, (JJ), Jerami Padi (JP), dan Jerami Kacang Tanah (JKT) yang ditambahkan suplemen UMMB pada sapi PO. Empat ekor sapi PO jantan dengan berat badan $\pm 100 \mathrm{~kg}$ berumur $12-$ 18 bulan digunakan pada penelitian ini. Rancangan bujur sangkar latin $4 \quad$ X 4 dengan 4 perlakuan. Perlakuan yang diterapkan adalah R1: Rumput Lapang + UMMB R2: Jerami Jagung + UMMB R3: Jerami padi + UMMB dan R4: Jerami Kacang Tanah + UMMB. Orthogonal kontras digunakan untuk membandingkan pengaruh antar perlakuan dari variabel yang diamati. Hasil penelitian ini menunjukkan perlakuan memberikan pengaruh yang sangat nyata $(\mathrm{P}<0,01)$ terhadap kecernaan NDF dan ADF. Orthogonal kontras $\mathrm{C} 1$ menunjukkan kecernaan NDF dan ADF RL (68,44\% dan $61,37 \%)$ lebih tinggi $(\mathrm{P}<0,05)$ dibanding kecernaaan limbah pertanian (JJ 65,25\% dan $58,59 \%$, JP $62,63 \%$ dan $52,80 \%$, serta JKT $67,53 \%$ dan $59,81 \%$ ). Orthogonal kontras $\mathrm{C} 2$ menunjukkan bahwa kecernaan $\mathrm{NDF}$ dan ADF JJ + JP nyata lebih rendah $(\mathrm{P}<0,05)$ dibanding JKT sedangkan orthogonal kontras C3 menunjukkan bahwa kecernaan NDF dan ADF JJ nyata lebih tinggi $(\mathrm{P}<0,05)$ dibanding JP.
\end{abstract}

*Korespondensi (corresponding author):

Email: bernat.tulung@gmail.com
Hasil penelitian ini mendapatkan kesimpulan bahwa :

1. Kecernaan NDF dan ADF RL lebih tinggi dibanding JJ, JP dan JKT.

2. Kecernaan NDF dan ADF JKT lebih baik dibanding JJ dan JP.

3. Kecernaan NDF dan ADF JJ lebih tinggi dibanding JP.

Kata kunci : kecernaan NDF dan ADF, limbah pertanian, UMMB, sapi PO

\section{ABSTRACT}

NDF AND ADF DIGESTIBILITY WHICH GET THE SUPPLEMENTED UREA MOLASSES MULTINUTRIENT BLOCK (UMMB) OF SOME CROP RESIDUES TYPE AND LOCAL GRASS ON ONGOLE CROSSBRED CATTLE. A research evaluating dry matter (DM) and organic matter (OM) digestibility of crops residues and local grass supplemented urea molasses multinutrient block (UMMB) on Ongole crossbred cattle (PO). Four male PO cattle, $12-18$ months of age with \pm $100 \mathrm{~kg}$ of body weight were used in this experiment. Latin Square Design 4 x 4 with 4 cows and 4 treatments was used. The treatments were : R1: UMMB + local grass, R2: UMMB + Corn straw, R3: $\mathrm{UMMB}+$ Rice straw, and R4: UMMB + peanut straw. The results showed that there were significant effect $(\mathrm{P}<0.01)$ of treatments on NDF and ADF digestibility. C1 showed that NDF and ADF digestibility of local grass $(68.44 \%$ and $61.37 \%)$ were higher $(\mathrm{P}<0.05)$ compared to crop residues (corn straw $65.25 \%$ and 
$58.59 \%$, rice straw $62.63 \%$ dan $52.80 \%$, and peanut straw $67.53 \%$ and $59.81 \%$ ) respectively. $\mathrm{C} 2$ showed that $\mathrm{NDF}$ and ADF digestibility of legume straw was higher than grasses straw; and C3 showed that $\mathrm{NDF}$ and $\mathrm{ADF}$ digestibility of rice straw was lower than corn straw. The results have concluded that : 1 . NDF and ADF digestibility of local grass were higher compared to crop residues.

2. NDF and ADF digestibility of legume straw (peanut straw) was higher than grasses straw (corn straw and ricce straw)

3. NDF and ADF digestibility of corn straw was higher than peanut straw.

Key words: NDF and ADF digestibility, crop residues, UMMB, ongole crossbred cattle

\section{PENDAHULUAN}

Dalam bidang peternakan, pakan adalah faktor utama yang menentukan produksi ternak. Salah satu kendala dalam pengembangan produksi ternak sapi yang ada di Indonesia adalah sulitnya memenuhi kebutuhan pakan baik dari segi kualitas maupun kuantitasnya.

Hijauan adalah bahan pakan utama ternak ruminansia seperti sapi yang dibutuhkan untuk memperlancar dan menjaga fungsi normal saluran pencernaan. di Indonesia, ketersediaan hijauan sangat dipengaruhi oleh faktor musim, dimana pada musim hujan tersedia dalam jumlah banyak dan cukup sedangkan pada musim kemarau ketersediaannya sangat terbatas, untuk mengatasi kekurangan pakan biasanya peternak memberi pakan limbah pertanian seperti jerami.

Rumput adalah bagian dari hijauan pakan yang mengambil peranan penting dalam makanan khususnya bagi ternak ruminansia serta proporsinya yang cukup besar dalam ransum. Menurut Badan Pusat Statistik Sulawesi Utara, di Sulawesi Utara, produksi padi sawah dan padi ladang 48,91 ton/ha pada tahun 2014 dan kandungan nilai nutrisi jerami padi yaitu BK 92,00\%, PK 5,31\%, SK 32,14\%, NDF 73,82\%, ADF 51,53\%. Pada tahun 2015, produksi jagung diperkirakan mencapai 300.490 ton biji kering dan kandungan nilai nutrisi jerami jagung adalah $\mathrm{BK}$ $50,00 \%$, PK 5,56\%, SK 33,58\%. Produksi kacang tanah tahun 2015 adalah 3964 ton dan kandungan nilai nutrisi jerami kacang tanah adalah BK 86,76\%, SK 30,27\%, PK $12,00 \%$.

Selain pakan berserat, ternak sapi juga memerlukan pakan tambahan atau pelengkap untuk melengkapi kekurangan nutrien yang dibutuhkan. Urea Molasses Multinutrient Block (UMMB) merupakan pakan tambahan yang tersusun dari urea, tetes tebu, bungkil kedele, tepung tulang, dedak, kapur, onggok, garam, dan mineral. Komponen UMMB mempunyai fungsi masing-masing yaitu urea sebagai sumber nitrogen bagi perkembangan mikroba rumen, molases sebagai sumber kabohidrat 
bagi mikroba dan mineral diperlukan oleh ternak untuk memenuhi kekurangan pada bahan pakan.

Pakan berserat seperti jerami padi, jerami jagung dan jerami kacang tanah mempunyai keterbatasan untuk dikonsumsi oleh ternak karena kecernaannya yang rendah. Kecernaan suatu bahan pakan dipengaruhi oleh beberapa faktor yaitu komposisi kimia pakan, bentuk fisik pakan dan level pemberian pakan.

Sapi Peranakan Ongole (PO) terkenal sebagai sapi pedaging dan sapi pekerja, mempunyai kemampuan adaptasi yang tinggi terhadap perbedaan kondisi lingkungan, dan memiliki tenaga yang kuat. Cirinya berwarna putih dengan warna hitam di beberapa bagian tubuh, bergelambir dan berpunuk.

Penelitian ini bertujuan untuk mengetahui kecernaan NDF dan ADF pakan Rumput Lapang, Jerami Jagung, Jerami Padi, dan Jerami Kacang Tanah yang di tambahkan suplemen UMMB pada sapi PO.

\section{MATERI DAN METODE PENELITIAN}

Penelitian ini dilaksanakan di sentra peternakan sapi PO yang ada di Desa Tonsewer, Kecamatan Tompaso Barat selama 40 hari mulai dari November 2016 sampai dengan Desember 2016. Ternak yang digunakan pada penelitian ini adalah sapi PO jantan, umur 12 - 18 bulan sebanyak 4 ekor dengan berat badan \pm 100 kg. Pakan yang diberikan adalah rumput lapang, jerami jagung, jerami padi, dan jerami kacang tanah, serta UMMB sebagai pakan suplemen.

\section{Metode Penelitian}

Penelitian ini menggunakan eksperimen Bujur Sangkar Latin (Latin Square Design) menurut petunjuk Steel dan Torrie (1991) 4 x 4 , dengan 4 ekor ternak dan 4 macam perlakuan.

$\mathrm{Yij}(\mathrm{t})=\mu+\mathrm{Bi}+\mathrm{Kj}+\mathrm{P}(\mathrm{t})+\operatorname{\varepsilon ij}(\mathrm{t}) \operatorname{dimana}$

$\mathrm{i}=1,2, \ldots \mathrm{n} ; \mathrm{j}=1,2, \ldots \mathrm{n} ;$ dan $\mathrm{t}=1,2$, $\ldots n$

Yij $(\mathrm{t})=$ nilai pengamatan pada baris ke-i, kolom ke-j yang mendapat perlakuan ke-t.

$\mu=$ nilai rata-rata umum

$\mathrm{Bi}=$ pengaruh baris ke- $\mathrm{i}$

$\mathrm{Kj}=$ pengaruh kolom ke- $\mathrm{j}$

$\mathrm{P}(\mathrm{t})=$ pengaruh perlakuan ke- $\mathrm{t}$

eij $(\mathrm{t})=$ pengaruh galat pada baris $\mathrm{ke}-\mathrm{i}$, kolom ke-j yang memperoleh perlakuan ke-t 
Untuk melihat pengaruh dari masingmasing perlakuan terhadap setiap variabel yang diamati, data hasil penelitian dianalisis dengan analisis keragaman yang sesuai denagn rancangan percobaan yang digunakan. Uji orthogonal kontras digunakan untuk melihat membandingkan pengaruh antar perlakuan atau antar kelompok perlakuan dari variabel yang diamati. Uji orthogonal kontras yang digunakan adalah :

C1: R1 vs R2 + R3 + R4 yaitu membandingkan antara rumput lapang dengan jerami jagung + jerami padi + jerami kacang tanah

$\mathrm{C} 2: \mathrm{R} 2+\mathrm{R} 3$ vs R4 yaitu membandingkan antara jerami jagung +jerami padi dibandingkan dengan jerami kacang tanah atau membandingkan antara jerami rumput-rumputan dengan jerami legum C3: R2 vs R3 yaitu membandingkan antara jerami jagung dengan jerami padi atau dengan kata lain membandingkan antara dua macam jerami rumput-rumputan

Variabel yang diamati adalah kecernaan NDF dan ADF.

Tabel 1. Komposisi nutrien dari bahan pakan penelitian (dasar bahan kering)

\begin{tabular}{|c|c|c|c|c|c|}
\hline \multicolumn{6}{|c|}{ Bahan Pakan } \\
\hline \multirow[t]{3}{*}{ Nutrien } & Rumput & & Jerami & Jerami Kacang & UMMB \\
\hline & Lapang & Jerami Jagung & Padi & Tanah & \\
\hline & $\mathrm{R} 1(\%)$ & $\mathrm{R} 2(\%)$ & $\mathrm{R} 3(\%)$ & $\mathrm{R} 4(\%)$ & \\
\hline Protein Kasar & 15,14 & 12,93 & 4,16 & 14,04 & 24,50 \\
\hline Lignin & 6,99 & 9,85 & 10,23 & 5,30 & 0,72 \\
\hline Silika & 3,62 & 4,95 & 5,27 & 0,77 & 1,08 \\
\hline NDF & 74,46 & 68,78 & 75,88 & 48,73 & 9,6 \\
\hline ADF & 42,93 & 42,36 & 52,18 & 31,28 & 5,4 \\
\hline BK & 22,26 & 43,23 & 44,83 & 44,97 & 76,50 \\
\hline $\mathrm{BO}$ & 92,019 & 91,94 & 77,92 & 92,15 & 76,30 \\
\hline
\end{tabular}

Sumber: Hasil Analisis Laboratorium Ilmu dan Teknologi Pakan Fakultas Peternakan IPB, Bogor 2016. 


\section{HASIL DAN PEMBAHASAN}

Data hasil penelitian tentang kecernaan $\mathrm{NDF}$ dan $\mathrm{ADF}$ pakan rumput lapang, jerami padi, jerami jagung dan jerami kacang tanah dengan suplemen UMMB pada sapi PO di sajikan pada Tabel 2. Hasil menunjukkan bahwa kecernaan NDF berkisar antara 62,63 68,44\%, sedangkan kecernaan ADF berkisar antara 52,80 - 61,37\%. Hasil analisis keragaman menunjukkan bahwa perlakuan memberikan pengaruh yang berbeda sangat nyata $(\mathrm{P}<0,01)$ terhadap kecernaan NDF dan ADF. Hasil uji orthogonal kontras $(\mathrm{C} 1, \mathrm{C} 2$ dan $\mathrm{C} 3)$ dari NDF dan ADF menunjukkan model yang sama.

Hasil uji orthogonal kontras $\mathrm{C} 1$ menunjukkan bahwa kecernaan NDF dan ADF rumput lapang nyata lebih tinggi $(\mathrm{P}<0,05)$ dibanding dengan kecernaan NDF dan ADF limbah pertanian. Tingginya kecernaan NDF dan ADF rumput lapang diduga karena kandungan protein rumput lapang $(15,14 \%)$ yang lebih tinggi dibanding dengan kelompok limbah pertanian (jerami jagung 12,93\%, jerami padi $4,16 \%$ dan jerami kacang tanah 14,04\%). Menurut Sarnklong et al., 2010 bahwa kecernaan jerami rendah karena sulit didegradasi oleh mikroba rumen. Jerami mempunyai beberapa kelemahan yaitu kandungan lignin dan silika yang tinggi serta rendah energi, protein, mineral dan vitamin. Dengan lebih tingginya kandungan protein kasar mengakibatkan mikroorganisme rumen dapat berkembang biak dengan lebih baik dan menghasilkan ensim-ensim lignoselulase yang lebih banyak untuk mencerna komponen dinding sel seperti NDF dan ADF. Selain hal tersebut di atas, rumput lapang ketika diberikan ke ternak masih dalam fase vegetatif sehingga komponen dinding selnya belum mengalami proses lignifikasi yang intens sehingga lebih mudah dicerna oleh enzimenzim ligno-selulase yang dihasilkan oleh mikroorganisme rumen, sedangkan limbah pertanian sudah melewati fase generatif dimana sel-sel tanaman sudah mengalami proses lignifikasi. Hal ini ditunjang oleh Van Soest (1986) yang menyatakan bahwa dinding sel tanaman terdiri dari tiga layer yaitu middle lamella, primary cell wall dan secondary cell wall dengan proporsi yang relatif tergantung dari tipe sel dan umur tanaman. Primary cell wall biasanya terdapat pada tanaman yang sedang tumbuh (Selvendran and O’Neil, 1987). Ketika tanaman mencapai dewasa (masa generatif) pembentukan secondary cell wall dimulai di dalam primary cell wall. Kandungan airnya berkurang secara signifikan (Salisbury and Ross, 1978) dan tempat air digantikan oleh lignin. Dinding sel menjadi lebih kaku dan tebal sebagai 
Tabel 2. Konsumsi dan Kecernaan NDF dan ADF selama penelitian.

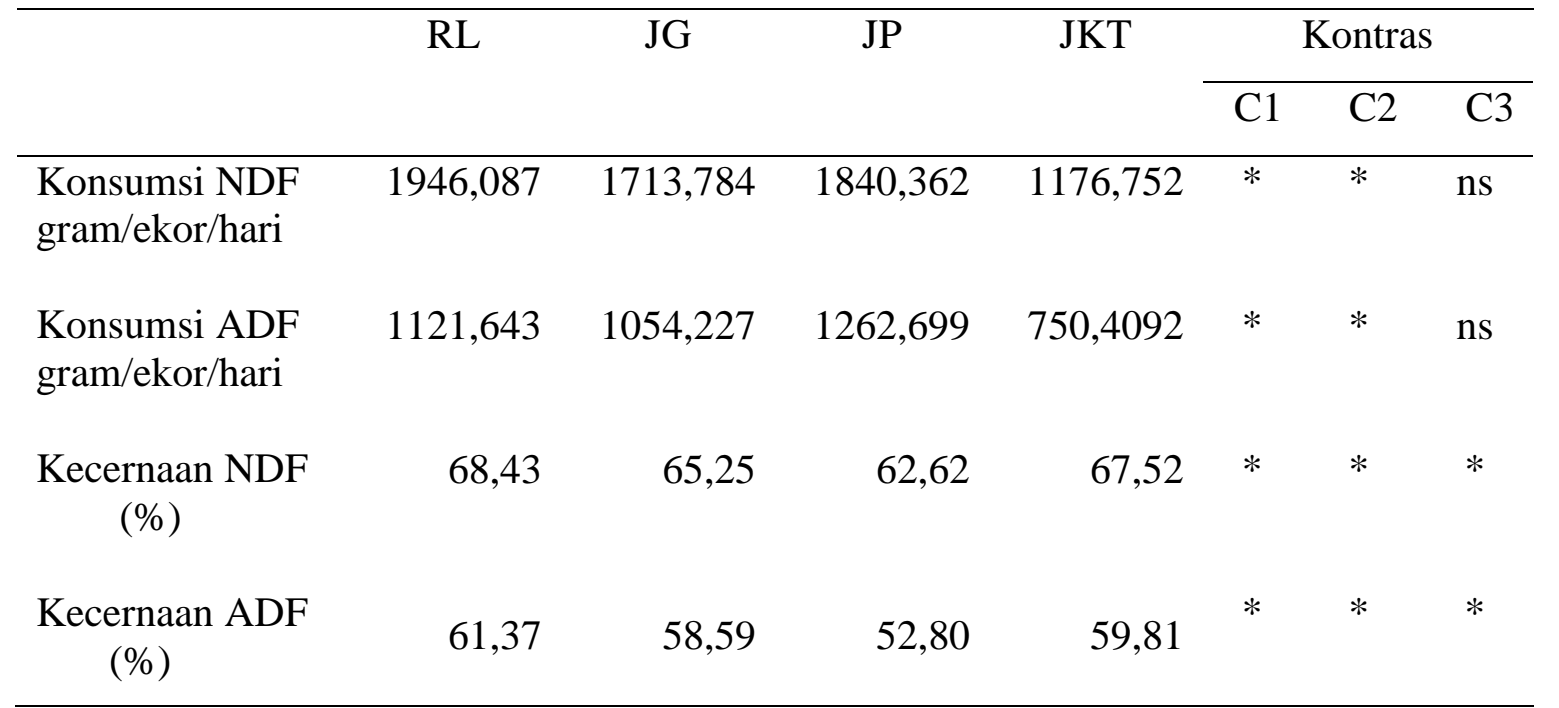

\footnotetext{
Keterangan :

$\mathrm{C} 1=$ Orthogonal kontras antara RL vs JG $+\mathrm{JP}+\mathrm{JKT}$

$\mathrm{C} 2$ = Orthogonal kontras antara JG + JP vs JKT (jerami rumput-rumputan vs jerami legum)

$\mathrm{C} 3=$ Orthogonal kontras antara jerami jagung vs jerami padi (antar jerami rumput-rumputan)
}

akibat dari lignifikasi. Proses ini dimulai di dalam primary cell wall menuju middle lamella (Fahey and Galeb, 1991) dan kecernaan dinding selnya menjadi menurun.

Uji orthogonal kontras (C2) menunjukkan bahwa kecernaan NDF dan ADF jerami kacang tanah (legum) nyata lebih tinggi $(\mathrm{P}<0,05)$ dibanding kecernaan jerami jagung dan jerami padi. Tingginya kecernaan NDF jerami legum diduga karena adanya perbedaan ratio arabinose : xylosa, dimana ratio arabinose:xylosa pada jenis legum lebih tinggi dibanding jenis rumput-rumputan. Maaruf (1986) meneliti ratio arabinose : xylosa dari beberapa jenis rumput-rumputan (brome grass, jerami jagung, jerami gandum dan jerami padi) berkisar antara 0,12 - 0,18; sedangkan ratio arabinose : xylosa pada jenis legum berkisar antara $0,19-0,24$. Hal ini ditunjang oleh Hatfield (1989) yang menyatakan bahwa banyaknya rantai cabang atau substitusi oleh rantai polisakarida pada hemiselulosa mengontrol seberapa besar hemiselulosa dapat berasosiasi dengan polisakarida lain melalui ikatan hydrogen. Carpita dan Gibeaut (1993) juga melaporkan bahwa rantai cabang arabinosa tidak hanya mencegah ikatan hydrogen antara linier xilan dengan glukosa, tetapi juga membuat rantai cabang menjadi larut air. McNeil et al (1975) menyatakan bahwa rendahnya rantai cabang arabinosa kemungkinan dapat meningkatkan tendensi pembentukan 
ikatan non kovalen antara xylosa dengan selulosa. Dimana ikatan ini akan menyebabkan dinding sel menjadi lebih kaku dan hal ini akan menurunkan kecernaan dinding sel (NDF). Buxton (1989) melaporkan bahwa arabinose : xylosa mempunyai hubungan positif dengan laju kecernaan dinding sel (NDF). Maaruf (1986) melaporkan bahwa laju degradasi dinding sel (NDF) di dalam rumen untuk legum berkisar antara 5,8 8,2 \%/jam, sedangkan laju degradasi NDF beberapa jenis rumput-rumputan (brome grass, jerami gandum, jerami jagung dan jerami padi) hanya berkisar antara 2,4 $3,6 \% / j a m$.

Orthogonal kontras (C2) kecernaan ADF jerami kacang tanah yang lebih tinggi dibanding jerami jagung dan jerami padi diduga karena jerami kacang tanah mengandung protein kasar lebih tinggi dari kedua jerami rumput-rumputan maka kecernaan ADFnya menjadi lebih tinggi. Hasil ini juga ditunjang oleh Maaruf (1986) yang menyatakan bahwa laju degradasi di dalam rumen dari beberapa jenis legum jauh lebih tinggi berkisar antara 5,5 - 7,9\% dibanding dengan laju degradasi beberapa jenis rumput-rumputan (brome grass, jerami gandum, jerami jagung dan jerami padi) yang berkisar antara $2,7-3,3 \% / j a m$.

Uji orthogonal kontras (C3) antara jerami jagung dan jerami padi menunjukkan bahwa kecernaan NDF dan ADF jerami jagung nyata lebih tinggi $(\mathrm{P}<0,05)$ dibanding jerami padi. Kecernaan NDF dan ADF jerami jagung adalah $65,25 \%$ dan $58,59 \%$, sedangkan kecernaan NDF dan ADF jerami padi berturut-turut adalah $62,63 \%$ dan $52,80 \%$. Tingginya kecernaan NDF jerami jagung diduga karena perbedaan ratio arabinosa : xylosa, dimana ratio pada jerami jagung \pm 0,16 sedangkan pada jerami padi $\pm 0,12$ (Maaruf and Paputungan, 2017). Seperti telah dijelaskan sebelumnya bahwa perbedaan ratio arabinose : xylosa akan mempengaruhi perbedaan kecernaan dinding sel. Selain itu laju degradasi dinding sel (NDF) di rumen untuk jerami jagung (3,2 - 3,4\% /jam) lebih tinggi ini dibanding jerami padi $(2,4-3,0 \% / j a m)$ (Maaruf 1986) sehingga hal ini mempengaruhi perbedaan kecernaan NDFnya. Lebih tingginya kecernaan ADF pada jerami jagung dibanding jerami padi diduga karena perbedaan kandungan protein, seperti telah dijelaskan sebelumnya bahwa perbedaan kandungan protein pakan akan mempengaruhi kecernaan zat-zat makanan. Selain itu laju degradasi ADF di dalam rumen juga mempengaruhi kecernaan. Kecernaan yang rendah pada jerami padi merupakan akibat dari struktur jaringan penyangga tanaman yang sudah tua. Jaringan tersebut sudah mengalami proses lignifikasi sehingga 
lignoselulosa dan lignohemiselulosa sulit dicerna (Balasubramanian, 2013). Maaruf (1986) menyatakan bahwa laju degradasi ADF jerami jagung berkisar antara 2,9 3,3\%/jam sedangkan jerami padi hanya berkisar antara 2,4-2,8\%/jam. Rendahnya kecernaan jerami padi juga mempunyai kandungan protein kasar yang rendah adalah 4,16\%. Hasil ini tidak jauh berbeda dengan Wanapat et al., (2013) bahwa kandungan protein kasar pada jerami padi sekitar 2-5\%. Hal ini sependapat dengan Lamid (2013) bahwa jerami padi mempunyai karakteristik kandungan protein kasar rendah serta serat kasar yang tinggi antara lain selulosa, hemiselulosa, lignin dan silika. Tingginya kecernaan jerami jagung karena memiliki kandungan nutrisi yang lebih bagus dari jerami padi. Hal ini sependapat dengan Bahar (2016) adalah jerami jagung

kandungan protein tinggi dan masih potensi sebagai sumber energi untuk sapi.

\section{KESIMPULAN}

Berdasarkan hasil penelitian
kecernaan ndf dan adf yang di suplementasi Urea Molasses Multinutrient Block (Ummb) bebasis limbah pertanian pada sapi peranakan ongole (PO) maka dapat disimpulkan bahwa:

1. Kecernaan NDF dan ADF rumput lapang lebih tinggi dibanding limbah pertanian (jerami jagung, jerami padi dan jerami kacang tanah).

2. Kecernaan NDF dan ADF jerami kacang tanah (legum) lebih baik dibanding jerami jagung dan jerami padi (jerami rumput-rumputan).

3. Kecernaan NDF dan ADF jerami jagung lebih tinggi dibanding jerami padi.

\section{DAFTAR PUSTAKA}

Bahar, S. 2016. teknologi pengelolaan jerami jagung untuk pakan ternak ruminansia. Buletin pertanian perkotaan.Vol 6 No 2. Balai Pengkajian Teknologi Pertanian. Jakarta.

Balasubramanian, M.K. 2013. Potential utilization of rice straw for ethanol production by sequential fermentation of cellulose and $x y-$ lose using Saccharomyces cerevisiae and Pachysolen tannophilus. International journal of Science, Engineering, Technology and Research 2(7): 1531-1535

Buxton, D. R. 1989. In vitro digestion kinetics of temperate perennial forage legume and grass stems. CropSci., 28:553-558

Carpita, N. C dan D.M. Gibeaut. 1993. Structural models of primary cell walls in flowering plants: Consistency of molecular structure with the physical properties of the wall during growth. Major Review. The plant J. 3(1):1-30 
Fahey, G. C. Jr dan K.A. Garleb. 1991. Forage Fibre Chemistry and Utilization. In: Proc. of the Pacific Northwest Nutrition Conference, Henschel. K. K. ed. pp. 51-65

Hatfield, R. D. 1989. Structural polysaccharides in forages and their digestibility. Agron. J. 81:3946

Lamid, M, N.N.T. Puspaningsih, dan M. Sarwoko. 2013. Addition of lignocellulolytic enzymes into rice straw improves in vitro rumen fermentation products. J. Appl. Environ. Biol. Sci., 3(9)166-171. ISSN: 2090-4274

Maaruf, K. 1986. Korelasi Antara Kecernaan In Situ Dan In Vitro Serta Komposisi Kimia Limbah Pertanian Untuk Kambing Dan Domba. Tesis. Fakultas pascasarjana. Universitas Gadjah Mada, Yogyakarta.

Maaruf, K. dan U. Paputungan. 2017. Comparison of protein and cell wall degradation of selected tropical and temperate roughages. Livestock Research for Rural Development.29 (6) 2017.

McNeil, M., P. Albersheim, I. Taiz, dan I. Jones. 1975. The structure of plant cell walls. VII. Barley aleurone cells. Plant physiol: 55:64-68

Salisbury, F. B. and C.W. Ross. 1978. Plant Physiology. 2nd ed. wadsworth Pub. Co. Incorporated, Belmont, California.

Sarnklong, C., J.W. Cone, W. Pellikaan, and W.H. Hendriks. 2010. Utilization of rice straw and different treatments to improve its feed value for ruminants: A Review. Asian-Aust. J. Anim. Sci.
23 (5): 680 - 692. DOI: https://doi.org/10.5713/ajas.2010.8 $\underline{0619}$

Selvendran, R. R, dan M.A. O’Neil. 1987. Isolation and analysis of cell walls from plants material. Meth. Biocham. Anal. 32:25

Van Soest, P. J. 1986. Nutritional Ecology of Ruminant. O dan B Books, Corvallis, OR.

Wanapat, M., S. Kang, N. Hankla, dan K. Phesatcha. 2013. Effect of rice straw treatment on feed in-take, rumen fermentation and milk production in lactating dairy cows. Afr. J. Agric. Res. 8(17): 16771687. 